\title{
PKMS PEMBUATAN TEPUNG DAUN LUHU (Ormocarpum Cochinchinense) YANG DITAMBAHKAN DALAM PAKAN UNTUK MENINGKATKAN IMUNITAS IKAN YANG DIBUDIDAYA DI KAMPUNG NAHEPESE
}

PKMS Making Luhu Leaf Flour (Ormocarpum cochinchinense) Which is added To Fish Feed To Increase The Immunity of Fish Cultivated In The Nahepese Village

\section{Darna Susantie, Usy Nora Manurung}

Program Studi Teknologi Budidaya Ikan, Politeknik Negeri Nusa Utara, Tahuna

Email : darunadayana@gmail.com

\begin{abstract}
Abstrak : Kepulauan Sangihe, budidaya ikan air tawar semakin berkembang dan dapat dilihat dibeberapa kampung yang memelihara ikan di pekarangan rumah. Untuk melakukan budidaya ikan, masyarakat memerlukan ilmu dan pengetahuan tentang cara budidaya ikan sehingga usaha budidaya yang dikelolah dapat berhasil. Untuk meningkatkan produksi dan keberhasilan budidaya ikan air tawar dapat dilakukan dengan cara pembuatan pakan. Pakan ikan harus mengandung nutrisi. Kegiatan penerapan Pengabdian Kemitraan Masyarakat Stimulus ini bertujuan membantu masyarakat pembudidaya ikan Kampung Nahepese dalam pembuatan pakan ikan dengan penambahan tepung daun luhu. Tujuan ini dapat dicapai lewat penerapan beberapa metode penambahan bahan herbal yaitu tepung daun luhu pada pakan yang mudah dipahami dan dimengerti masyarakat secara mandiri. Tahapan pelaksanaan kegiatan meliputi pembuatan pakan ikan yang ditambahkan tepung daun luhu, kemudian memberi materi tentang cara budidaya ikan air tawar, pengelolaan kualitas air, serta hama dan penyakit ikan. Dengan kegiatan ini, masyarakat Kampung Nahepese memahami pembuatan tepung daun luhu yang akan ditambahkan ke dalam pakan ikan. Kegiatan Stimulus ini berdampak positif dan sangat baik dalam meningkatkan budidaya ikan air tawar di Kepulauan Sangihe.
\end{abstract}

Kata kunci : Imunitas, Luhu, Ormocarpum cochincinense, pertumbuhan.

\begin{abstract}
In Sangihe Islands, freshwater fish farming is growing and can be seen in several villages that keep freshwater fish in their yards. To carry out fish cultivation, the fish cultivator community needs knowledge about how to cultivate fish so that the cultivation business that is managed can be successful. To increase the production and success of freshwater fish cultivation can be done by making feed. Fish feed that is made must contain nutrients. The activity of implementing the Stimulus Community Partnership Service aims to help the fish cultivator community in Nahepese Village in demonstrations of making fish feed with the addition of herbal ingredients. This goal can be achieved through the application of several methods of adding herbal ingredients, namely luhu leaf flour to feed that is easily understood by the community independently. The stages of implementing this activity include the application of adding luhu leaf meal to the feed, then an explanation of how to cultivate freshwater fish, management of water quality, fish pests and diseases, and. With this activity, community Nahepese Village have a better understanding include of luhu leafflour in fish feed. This Stimulus activity has a positive and good impact in increasing freshwater fish farming in Sangihe Islands.
\end{abstract}

Keywords : Immunity, Luhu, Ormocarpum cochincinense,, growth 


\section{PENDAHULUAN}

Usaha Budidaya ikan air tawar semakin berkembang yang dapat dilihat di beberapa kampung yang membudidayakan ikan air tawar di pekarangan rumah. Untuk melakukan budidaya ikan, petani ikan memerlukan ilmu dan pengetahuan tentang cara budidaya ikan dan beberapa aspek penting terkait lainnya sehingga usaha budidaya yang dikelolah dapat berhasil dan dapat meningkatkan perekonomian rumah tangga. Jenis-jenis ikan yang dibudidaya di Kampung Nahepese, Kecamatan Manganitu yaitu ikan nila (Oreochromis niloticus), ikan Mas (Cyprinus carpio), ikan bawal (Colossoma macropomum), dan beberapa jenis ikan hias.

Cara budidaya ikan air tawar seperti ikan nila, mas dan bawal belum banyak dipahami dan dimengerti oleh masyarakat Kampung Nahepese sehingga kegiatan PKMS dilakukan untuk merangsang masyarakat kampung dalam budidaya ikan air tawar secara serius dan dapat dijadikan suatu usaha yang bisa menambah penghasilan dan meningkatkan taraf hidup keluarga. Selain cara budidaya ikan air tawar yang baik, masyarakat Kampung Nahepese hanya memelihara ikan tanpa memperhatikan pakan yang diberikan tersebut bergizi atau tidak. Hasil survey yang dilakukan dimana masyarakat belum memahami cara memelihara ikan dan pakan untuk meningkatkan imunitas ikan.

Keunggulan ikan nila, ikan mas, dan ikan bawal adalah mudah dikembangbiakan, pertumbuhan relatif cepat, pemakan segala (omnivora), memiliki toleransi terhadap perubahan lingkungan, kelangsungan hidup tinggi serta tahan terhadap perubahan kondisi lingkungan (Santoso, 1996; Rukmana, 1997; El-Sayed, 2006; Khairuman dan Amri, 2008; Sallata, 2015; Aliyas et al., 2016; Taufik et al., 2016; Fatchurochman et al., 2017).

Pakan merupakan salah satu komponen paling penting dalam pertumbuhan ikan dan dalam usaha budidaya ikan. Pakan buatan adalah pakan yang dibuat dan disesuaikan dengan jenis ikan (Afrianto dan Liviawaty, 2005).

Penggunaan bahan herbal dikatakan ramah lingkungan karena bahan herbal yang dipakai akan mudah terurai di alam dibandingkan bahan kimia buatan sehingga dengan pemakaian bahan herbal tidak mencemari lingkungan serta ikan yang dihasilkan aman untuk dikonsumsi. Bahan herbal yang digunakan dalam kegiatan ini adalah tepung daun luhu (Nama ilmiah). Daun luhu merupakan tanaman yang mengandung antioksidan yang dapat 
meningkatkan sistem imun dan pertumbuhan ikan. Kandungan nutrisi daun luhu adalah energi $59 \mathrm{kal}$, protein 6,4 gr, lemak 1,6 gr, karbohidrat 9,9 gr, air 81 gr, dan serat 1,5 gr (Menurut siapa??). Menurut Maria John et al., 2011; Sivakumar, T dan D. Gajalakshmi, 2013; Pazhanisamy, M dan G.A.I. Ebenezer, 2013; Kumar et al., 2013; Srividya et al., 2014; Srividya et al., 2015; Sridevi, G, 2016 bahwa daun luhu (O. cochinchinense) merupakan tanaman yang mengandung antioksidan dan dijadikan sebagai bahan herbal.

$$
\text { Kurangnya informasi dan }
$$
pengetahuan tentang cara budidaya ikan air tawar serta penggunaan bahan herbal dalam pakan ikan bagi masyarakat Kampung Nahepese sehingga perlu dilakukan penerapan IPTEKS untuk menambah pengetahuan masyarakat kampung tersebut. Pengabdian ini, memberikan hasil yang baik untuk pembudidaya ikan dan masyarakat Kampung Nahepese Kecamatan Manganitu. Berdasarkan masalah yang diselesaikan adalah :kendala masyarakat mengenai informasi pengetahuan tentang cara budidaya ikan air tawar dan faktor-faktor pendukung dalam budidaya ikan air tawar 2) kendala kurangnya informasi masyarakat tentang penggunaan daun luhu dalam pakan ikan sebagai imunitas dan dapat meningkatkan pertumbuhan ikan.

Dengan adanya kegiatan ini mitra Kampung Nahepese dapat menjadi sentra budidaya ikan air tawar yang mampu menyediakan benih ikan dan ikan konsumsi yang unggul di Kabupaten Kepulauan Sangihe, masyarakat mampu membuat pakan mandiri dari bahan herbal yaitu luhu.

\section{METODE PELAKSANAAN}

\section{Waktu dan Tempat Kegiatan}

Kegiatan Program Kemitraan Masyarakat Stimulus dilaksanakan pada tanggal 29 Agustus 2020 berlokasi di Kampung Nahepese, Kecamatan Manganitu.

\section{Metode Pelaksanaan Pengabdian}

Metode-metode yang digunakan dalam pelaksanaan Pengabdian Kemitraan Masyarakat Stimulus adalah metode pendidikan, metode pelatihan dan metode pendampingan yang dilakukan adalah :

1) Ceramah tentang pentingnya cara budidaya ikan air tawar yang baik pengelolaan kualitas air dan bahan herbal (tepung daun luhu).

2) Demonstrasi langsung tentang cara pembuatan pakan dengan penambahan bahan herbal tepung daun luhu pada pakan ikan. 


\section{Tahapan Pelaksanaan Pengabdian}

Tahapan pelaksanaan kegiatan

Pengabdian Kemitraan Masyarakat Stimulus adalah :

1) Tahap persiapan untuk penentuan lokasi kegiatan pengabdian dan mengurus perijinan pelaksanaan PKMS.

2) Tahap Persiapan Pelaksanaan yaitu mempersiapkan surat ijin, peralatan yang dibutuhkan, dan modul pengabdian.

3) Tahap pelaksanaan pengabdian dengan memberi materi tentang cara budidaya ikan air tawar, pengelolaan kualitas air untuk budidaya ikan dan demonstrasi langsung cara pembuatan bahan herbal yang ditambahkan dalam pakan ikan serta memberi bantuan.

4) Tahap terakhir yaitu monitoring dan Evaluasi kegiatan PKMS.

\section{HASIL DAN PEMBAHASAN}

\section{Hasil Kegiatan Pengabdian}

Kegiatan Pengabdian Kemitraan

Masyarakat Stimulus di Kampung Nahepese dapat terlaksana dengan baik karena adanya dukungan dari berbagai pihak yang terkait dalam pelaksanaannya dalam hal ini yaitu masyarakat Kampung Nahepese dan mitra yang menyediakan tempat untuk kegiatan
Pengabdian Kemitraan Masyarakat Stimulus, pada hari Sabtu, 29 Agustus 2020 dihadiri oleh masyarakat pembudidaya ikan Kampung Nahepese. Kegiatan pengabdian dilakukan dengan memberikan materi tentang budidaya ikan air tawar, pengelolaan kualitas air budidaya ikan, dan demonstrasi pembuatan bahan herbal (tepung daun luhu) serta cara penambahan tepung daun luhu ke dalam pakan ikan. Animo masyarakat terhadap materi yang disampaikan ditanggapi oleh masyarakat dalam bentuk pertanyaan. Masyarakat pembudidaya ikan air tawar sangat tertarik dengan semua materi yang diberikan terlebih penggunaan bahan herbal yang mudah didapat di sekitar rumah, murah, dan praktis dalam pembuatan. Bahan herbal yang dimaksudkan dalam materi adalah bahan yang mudah diperoleh dari lingkungan tempat tinggal.

Selain ketertarikan ke bahan herbal, masyarakat pembudidaya menanyakan tentang cara mudah dalam hal mengetahui penyakit ikan? bagaimana solusinya dalam pencegahannya? Melihat antusias masyarakat dalam kegiatan ini, tim kami langsung memberikan cara yang mudah untuk melihat ikan yang terkena penyakit. Dimana disamping kegiatan ini, ada kolamkolam budidaya ikan seperti ikan nila, mas, bawal, dan ikan hias air tawar seperti ikan koi 
dan ikan mas koki. Di kolam ikan nila yang bercampur dengan ikan mas, tim kami langsung mengambil sampel 2 ekor ikan nila yang terkena penyakit seperti jamur pada tubuh ikan dan ketidak-lengkapan sirip ikan (putus). Kemudian memberikan cara praktis dengan memberikan garam ke dalam loyang yang berisi air kemudian ikan direndam kurang lebih setengah jam. Kemudian ikan tersebut dilepas ditempat yang berbeda sehingga tidak memberi dampak ke ikan yang lain. Contoh praktis seperti ini, yang sangat dibutuhkan masyarakat dalam penanganan awal ketika ikan terkena penyakit. Dalam kesempatan itu juga diberikan bantuan kepada masyarakat berupa benih ikan nila, pakan komersial, baki, loyang, sendok, dan alat pencetak pelet.

Dari kegiatan pengabdian tersebut masyarakat mengusulkan kepada tim pengabdian kami untuk dapat melanjutkan pengabdian di tahun berikutnya tentang penggunaan bahan-bahan herbal lainnya yang ada di sekitar Kampung Nahepese, bagaimana cara budidaya ikan bawal dan memilih induk jantan dan betina ikan bawal, serta pembenihan/pemijahan pada ikan bawal, sehingga masyarakat dapat mempunyai stok benih ikan bawal.

Kegiatan monitoring dilakukan untuk mengontrol keadaan atau perkembangan budidaya ikan yang diberikan pada saat pengabdian dan juga untuk melihat tindak lanjut pertumbuhan ikan yang diberi pakan tambahan tepung daun luhu yang dilakukan oleh masyarakat. Dari hasil monitoring masyarakat telah membuat sendiri tepung daun luhu yang ditambahkan dalam pakan ikan. Masyarakat mudah memahami dan mengerti cara pembuatan pakan dengan bahan herbal yang bisa diaplikasikan secara langsung, praktis cara pembuatannya dan ekonomis serta dapat memanfaatkan bahan-bahan hetbal yang berasal dari tumbuhan yang ada disekeliling tempat tinggal yang ada di Kampung Nahepese.

\section{Luaran Yang Dicapai}

Target luaran dari kegiatan pengabdian ini adalah masyarakat Kampung Nahepese memahami budidaya ikan air tawar, pengelolaan kualitas air untuk budidaya ikan air tawar, dan membuat secara mandiri tepung daun luhu dan kemudian ditambahkan pada pakan ikan.

Dengan pengetahuan yang dibekali dalam kegiatan ini dapat merangsang masyarakat Kampung Nahepese lebih fokus ke usaha budidaya ikan air tawar menjadi suatu bisnis masa depan sehingga Kampung Nahepese dapat menjadi sentra budidaya ikan 
air tawar dan dapat menyediakan stok ikan konsumsi maupun benih ikan.

Target luaran dari kegiatan Pengabdian Kemitraan Masyarakat Stimulus yaitu dalam bentuk metode, produk, dan artikel ilmiah.

Pada hakekatnya, kegiatan PKMS ini merupakan solusi terhadap permasalahan yang dihadapi mitra melalui pendekatan secara terpadu, agar dapat meningkatkan nilai ekonomis masyarakat serta pendapatan keluarga. Adapun perubahan pasca PKMS yang diharapkan, masyarakat/mitra dapat meningkatkan budidaya ikan air tawar menjadi suatu bisnis masa depan dan menjadikan Kampung Nahepese sebagai Sentra budidaya ikan air tawar.

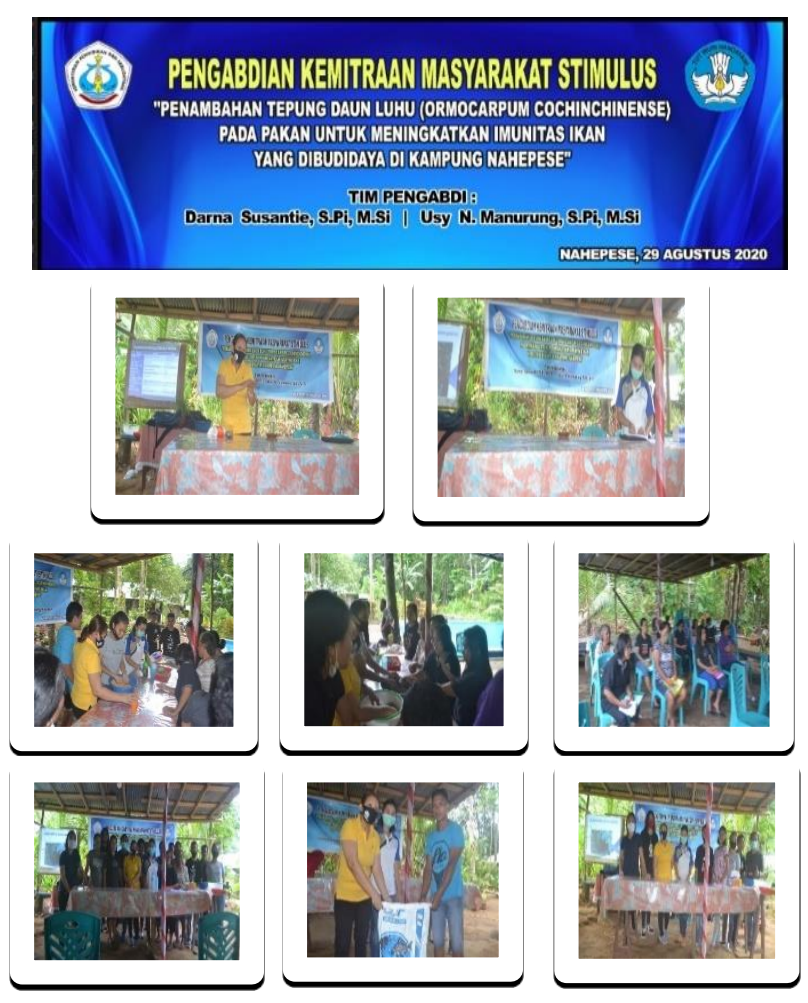

\section{Rencana tahapan berikutnya}

Animo masyarakat Kampung Nahepese yang begitu baik menerima tim Pengabdian Polnustar. Masyarakat mengharapkan Tim Pengabdian Polnustar dapat melanjutkan kegiatan ini untuk tahun depan di Kampung Nahepese dalam membantu memecahkan beberapa masalah, sebagai berikut :

1) Bagaimana cara budidaya ikan bawal?

2) Bagaimana cara memilih ikan bawal untuk dijadikan induk?

3) Berapa umur ikan bawal yang dapat dijadikan induk?

4) Bagaimana cara pemijahan, pembenihan ikan bawal, serta faktor penunjang lainnya (dalam hal ini dapat menyediakan stok benih ikan bawal)?

Melihat keingintahuan yang besar dari masyarakat Kampung Nahepese, membuat tim saya ingin melanjutkan program PKMS di kampung tersebut dengan membawa bekal ilmu pengetahuan serta IPTEK yang lebih baik lagi dalam menunjang kegiatan budidaya di Kampung Nahepese. Harapan terbesar tim saya, khususnya saya sebagai ketua Pengabdi berharap Kampung Nahepese dapat menjadi sentra budidaya ikan air tawar serta dapat menyediakan stok ikan konsumsi dan benih ikan bawal dan ikan air tawar lainnya. 


\section{KESIMPULAN}

Kegiatan Pengabdian Kemitraan

Masyarakat Stimulus (PKMS) di Kampung Nahepese dapat memberikan solusi terbaik dalam budidaya ikan air tawar seperti pengelolaan kualitas air, membedakan ikan jantan dan betina, memilih benih dan induk unggul, dan penanganan hama/penyakit pada ikan.

Masyarakat pembudidaya Kampung Nahepese dapat membuat pakan ikan dengan penambahan tepung daun luhu secara mandiri.

\section{DAFTAR RUJUKAN}

Afrianto dan E. Liviawaty. 2005. Pakan Ikan dan Perkembangannya. Penerbit. Kanisius. Yogyakarta.

Aliyas, Samliok Ndobe, dan Zakirah Raihani Ya'La. 2016. Pertumbuhan dan Kelangsungan Hidup Ikan Nila (Oreochromis sp) Yang Dipelihara Pada Media Bersalinitas. Jurnal Sains dan Teknologi Tadulako. 5(1)19-27.

El-Sayed, A. F. M. 2006. Tilapia Culture. Wallingford, Oxfordshire, UK : CABI Publishing is a division of $\mathrm{CAB}$ International.

Fatchurochman, Vava, Rachmawati D, dan Hutabarat Johannes. 2017. Pengaruh Kombinasi Pemberian Enzim papain Pada Pakan Buatan dan Probiotik Pada Media Pemeliharaan Terhadap Efisiensi Pemanfaatan Pakan, Pertumbuhan, dan Kelulushidupan Ikan Bawal Air Tawar (Colossoma macropomum). Journal of Aquaculture Management and Technology 6(3):30-39.Universitas Diponegoro. http://ejournals1.undip.ac.id/index.php/jamt
Kumar, D, Maria John K.M, dan Karthik, S. 2013. The Bone-healing Potential of Ormocarpum cochichinense, Methanolic Extract On Albino Wistar Rats. Journal of Herbs, Spices and Medical Plants 19:1-10.

Khairuman dan Khairul Amri. 2008. Buku Pintar Budidaya 15 Ikan Konsumsi. Penerbit PT. AgroMedia Pustaka. Jakarta.

Maria John K.M, D. Venkatesan, S. Sandhiya, S. Karthik dan S. Natarajan. 2011. In Vitro Sinthesis Of Calcite Crystal From Ormocarpum cochinchinense (L) A Traditional Bone Healing Aid Of Southern Asia. American Journal Pf Plant Physiology. 6(1):312-317.

Pazhanisamy, M dan G.A. I. Ebenezer. 2013. Antioxidant Activity Of Leaves Od An Important Medicinal Plant Ormocarpum cochinchinense (Lour) Merr. Journal of Modern Biotechnology. 2(5):

Rukmana, Rahmat. 1997. Ikan Nila, Budidaya dan Aspek Agribisnis. Yogyakarta: PT. Kanisius

Sallata, M. K. 2015. Konservasi dan Pengelolaan Sumber Daya Air Berdasarkan Keberadaannya Sebagai Sumber Daya Alam. Info Teknis EBONI, Vol. 12 No. 1:75-86.

Santoso, B. 1996. Budidaya Ikan Nila. Penerbit Kanisius. Yogyakarta.

Sivakumar, T dan D. Gajalakshmi. 2013. In Vitro Antioxidant and Chemical Constituents From The Leaves of Ormocarpum cochinchinense Elumbotti. American Journal of Plant Physiology. 8(1):114-122.

Sridevi, G. 2016. Anti-Arthritic and AntiInflammatorry Activity of Ethanolic Leaf Extract of Ormocarpum sennoides. Article 8(5):117-121 
Srividya, S, T.P. Sastry, dan G. Sridevi. 2014. Phytochemical Screening and In Vitro Antioxidant Activity of Ethanolic Extract of Ormocarpum sennoides. Int J Pharm Biol Sci. 8(2):775-780

Srividya, S, T.P. Sastry, B. Santhosh Kumar, dan T. Hemalatha. 2015. Osteopotential bone graft containing porous biphasic calcium phosphate impregnanted with casein, egg yolk and Ormocarpum sennoides an In Vitro Study. Int J. Phram Biol Sci. 6(1)
Taufiq, Firdaus, dan Iko Imelda Arisa. 2016. Pertumbuhan Benih Ikan Air Tawar (Colossoma macropomum) Pada Pemberian Pakan Alami Yang Berbeda. Jurnal Ilmiah Kelautan dan Perikanan UnSyiah. 1(3):355-365. 